\title{
EPTCAST - A PROPOSAL FOR SCIENTIFIC DISSEMINATION IN BRAZILIAN PROFESSIONAL AND TECHNOLOGICAL EDUCATION
}

\section{ORIGINAL ARTICLE}

RAMOS, Rogério Luiz da Silva ${ }^{1}$, FECURY, Amanda Alves², OLIVEIRA, Euzébio de ${ }^{3}$, DENDASCK, Carla Viana ${ }^{4}$, DIAS, Claudio Alberto Gellis de Mattos ${ }^{5}$

RAMOS, Rogério Luiz da Silva. Et al. EPTCast - A proposal for scientific dissemination in brazilian professional and technological education. Revista Científica Multidisciplinar Núcleo do Conhecimento. Year 06, Ed. 06, Vol. 07, pp. 89103. June 2021. ISSN: 2448-0959, Access link: https://www.nucleodoconhecimento.com.br/education/professional-andtechnological, DOI: 10.32749/nucleodoconhecimento.com.br/education/professionaland-technological

\section{SUMMARY}

This work consists of an experience report regarding the development of EPTCast, educational product developed throughout the professional master's course in Professional And Technological Education in National Network (ProfEPT). Based on the lack of scientific dissemination specifically focused on the field of Brazilian Professional and Technological Education (EPT), this work aims to promote initiatives in this sense, thus contributing to the popularization of the scientificity of this area. To this end, here, the process of construction and distribution via podcast of an audio

\footnotetext{
${ }^{1}$ Graduated in Foreign Trade, Specialist in Production Engineering (UNINTER), Professor and researcher at the Institute of Basic, Technical and Technological Education of Amapá (IFAP), Student of the Graduate Program in Professional and Technological Education (PROFEPT IFAP).

${ }^{2}$ Biomedical, PhD in Tropical Diseases, Professor and researcher of the Medical Course of Macapá Campus, Federal University of Amapá (UNIFAP).

${ }^{3}$ Biologist, PhD in Tropical Diseases, Professor and researcher of the Physical Education Course, Federal University of Pará (UFPA).

${ }^{4}$ Theologian, PhD in Clinical Psychoanalysis. She has been working for 15 years with Scientific Methodology (Research Method) in Scientific Production Guidance for Masters and Doctoral Students. Specialist in Market Research and Health Research. Doctoral Student in Communication and Semiotics (PUC SP).

${ }^{5}$ Biologist, PhD in Theory and Behavior Research, Professor and researcher of the Chemistry Degree Course of the Institute of Basic, Technical and Technological Education of Amapá (IFAP) and the Graduate Program in Professional and Technological Education (PROFEPT IFAP).
} 
content aimed at the scientific dissemination of the Brazilian EPT is portrayed. In this sense, initially the issue of the gap is addressed, and, therefore, the need to popularize the scientificity of this area. In a second moment, the design and technologies used in the construction of the EPTCast object are presented. Popularizing the scientificity of Brazilian Professional and Technological Education is what is intended through this work - which will not be the only one. Through what was exposed in the previous sections, therefore, it is intended to contribute to the popularization of a scientificity that is sometimes not yet understood as such.

Keywords: Podcast, Scientific Dissemination, Professional and Technological Education.

\section{INTRODUCTION}

Scientific dissemination is a practice adopted from the premise of the distance between the scientific community and the non-specialized public. In this sense, this communicative effort has been presented as a pedagogical discursive instrument of knowledge construction that aims at bringing scientific processes closer to the general public (MOIRAND, et ali, 2016).

Therefore, with the advent of the dissemination of the worldwide network of computers through the Internet, scientific dissemination finds more space to develop. This is perceived through the variety of digital media where this activity manifests itself: from texts on blogs, videoson dedicated platforms and also through podcasts (DE-LARAGONZÁLEZ and DEL-CAMPO-CAÑIZARES, 2018).

With its first reference dated in 2004, the media podcast has become popular in the field of communication. From the increasing amount and variety of options, ordinary people, companies, and even traditional media companies have been producing and distributing their content through this media (RIVERA SALAS and MONTOYA MÁRQUEZ, 2019).

Faced with the already consolidated, the podcast media has simple and accessible processes, whether for its production or consumption. Thus, this presents itself as a 
reason for this media to be used in the distribution of educational content. However, when it comes to scientific dissemination, this movement is less frequent (DANTASQUEIROZ, WENTZEL and QUEIROZ 2018).

Specifically regarding the scientific dissemination in Brazilian Professional and Technological Education (EPT), there is a void. Understood as an instrument of social ascension, this area of research has been building knowledge necessary to improve the conditions of the popular working classes so that, in fact, society as a whole develops (MOURA, 2013).

\section{GOAL}

Portray the process of construction of EPTCast in order to foster larger and better initiatives, in order to contribute to the popularization of the scientificity produced in the field of Brazilian EPT.

\section{MATERIALS AND METHODS}

Developed by those who see the integration between Education and Work as a path for the social development of the popular working classes, EPTCast is constituted through an audio content aimed at the scientific dissemination of the Brazilian EPT. Distributed through the media podcast, this is an Educational Product started in the first half of 2020 and developed throughout the professional master's course in Professional And Technological Education in National Network (ProfEPT).

The first challenge for the construction of this proposal was the creation of a visual identity, which required the design of a name, a slogan and a graphic symbol. A visual identity is, as a rule, designed for the best possible communication through verbal and/or non-verbal signs (MILLER and TOMAN, 2014). Therefore, given the need for distribution through the Internet - which strongly requires the presence of visual resources for the propagation of content (LIU, 2020) - this was the first demand in the construction of this Educational Product. 
Then, for the conception of the name, preference was initially given for something objective and that was directly associated with its mode of communication. In this sense, and above all, from the understanding that the names - whether for ideas, products or services - are always built within an existing structure, which causes a new name to carry part of others (NDERITU PATRICK, 2016), we chose to ally the acronym of 'Educação Profissional e Tecnológica' with the last part of the name of its distribution media 'cast'. As a result, the name EPTCast was created.

Then, for the continuation of the development of visual identity, a slogan was built. Short phrase and quick association with the idea proposed by name, a slogan aims to present briefly the concept of a work (MILLER and TOMAN, 2014). Thus, we chose to describe the distribution media together with the proposed content. Soon, the name EPTCast adopted the following slogan:"Seu podcast sobre Educação Profissional e Tecnológica".

Finally, after the conception of the name and its slogan,it was followed by the construction of a graphic symbol. Also known as logo, this is a visual feature that aims at communication with the interested public. In this perspective, the visual identity of a brand should be a simple and intelligible communication tool (BOLHUIS et ali, 2015). Thus, we chose the use of a Dialogue Balloon. Finally, for the construction of the elaborate idea, we made use of the free version of the online platform for creating drawings and layouts, Canva.com.

Following the development of visual identity, the materialization of the EPTCast Educational Product had the production and distribution activities. The Production consisted of the work of Scripting, Capturing and Editing audio content. For these tasks, the text editing software Microsoft Word version 2016, the audio editing software Audacity version 2.3.1, and audio features of the YouTube (audiolibrary)and Freesound.org platforms were used as working instruments.

In turn, the Distribution was carried out through the use of the Anchor.fm. For the identification of the material produced, the spaces dedicated to this task were used directly on the Anchor.fm platform, which automatically inserted the contents of 
EPTCast in the following digital audio platforms: Apple Podcasts; Breaker; Castbox; Google Podcasts; Overcast; Pocket Casts; RadioPublic and Spotify.

\section{RESULTS AND DISCUSSIONS}

The work used throughout the development process of this Educational Product was the result of hours of previous consumption of scientific dissemination content distributed via podcast. However, because there are rare references in the area of Brazilian EPT in the case of these specificities, the following results may, at the same time, present limitations regarding its construction, and opportunities for the development of more robust proposals.

\section{VISUAL IDENTITY}

Through the use of the free version of the Canva.com platform (https:canva.com) the construction of the visual identity of the EPTCast Educational Product began. For your canvas was chosen the size of 1500 by 380 pixels and color \#000000. For the name, the Montserrat Classic typographic font in bold style with size 50 and color of the \#000000. Then, the slogan was worked,which preserved the same typographic font and style applied to the name, but received changes in size and color, respectively 38 and \#fffff. Finally, a Dialog Balloon has been selected within the 'Shapes' option under 'Elements' on the platform in use. After insertion, the element was resized to size 365 by 290 pixels and color \#ffbf00 (Figure 1).

Figure 1 - Visual identity of the EPTCast Educational Product.

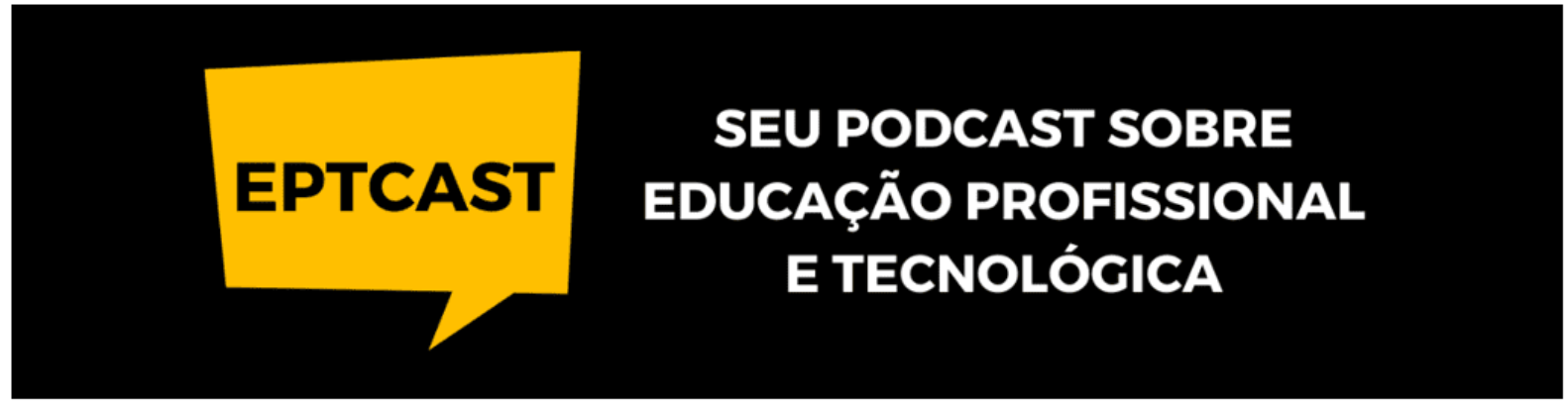


The visual identity of this Educational Product was designed so that it could be applied in future in digital spaces and physical promotional products. Therefore, since the beginning of its construction, it was established that this identity should be characterized through a simple image and multiple applicability.

Within this proposal, to the name, specifications were applied that met the planned. In order to maintain the central characteristic of the name, the slogan preserved the same idea, however, given the larger number of letters, its size was reduced and, in order to be read in front of the canvas, its color was changed. The Dialogue Balloon was applied for the recognition of the communicative proposal. Its differentiated color and the option of positioning the name in front of it was designed so that they could also be presented independently to the slogan.

\section{PRODUCTION}

From January 2020 to September of the same year, the production of this Educational Product resulted in 19 audios (\#00 to \#18). At first - until the publication of the 12th the content was developed through recurring subjects in the literature of the Brazilian EPT. From the 14th, it began to produce and publish through suggestions of topics sent by the audience, which made use of the channels of communication eptcast.com.br (comments), and the e-mail contato.eptcast.com.br. The 13th audio posted was intended to summarize the content so far presented and stimulate audience participation.

\section{SCRIPTING}

After the completion of the visual identity, the scripting was performed through the use of the proprietary text editing software Microsoft Word, version 2016 (https://office.com). From the use of this tool, the construction of the content developed in 03 parts, "Apresentação", "Evolução" and "Conclusão" (Table 1) began.

The "Apresentação" was subdivided into other 03 parts, where, the first 'Opening', was dedicated to the welcome, presentation of the announcer and identification of the 
program. Then, 'Context', was focused on identifying the conjuncture of the phenomenon addressed. Finishing the block "Presentation", the 'Call to action' block is used,at which time the audience is invited to interact by electronic means at the end of the audio.

The next moment, "Evolution", was divided into 04 parts. The first, 'Phenomenon', was dedicated to the summary about the treated object. Next 'Antecedents' and 'Characteristics' were spaces focused on the approach of the development process of the phenomenon in question and its properties. Finally, 'Desdobramentos', devoted itself to the consequences in the social context, especially for Education and Work.

The "Conclusão" was divided into 03 parts. The first, 'Reflexão' was dedicated to succinct observations on the subject dealt with. The next moment, 'References', aimed to inform the audience about the place of lodging of the material used in the construction of the script. Finally, the 'Call to action' feature was used.

Table 1 - Narrative scheme of the script.

\begin{tabular}{c|c|c}
\hline Apres entação & Evolução & Conclusão \\
\hline Abertura & Fenômeno & Reflexão \\
(30 segundos $)$ & (01 min. e 30 segs. $)$ & (02 mins. e 30 segs.) \\
Contexto & Antecedentes & Referências \\
(01 minuto) & (01 min. e 30 segundos $)$ \\
Call to action & Características & Call to action \\
(30 segundos) & (03 minutos.) & (01 minuto) \\
\hline & Desdobramentos & \\
\hline 02 minutos & (03 minutos.) & 04 minutos \\
\hline
\end{tabular}

The composition elements of the narrative scheme were thought in such a way as to make the listener understand the relationship between the treated phenomenon and 
the current reality within the context of Education and Work. The time dedicated to each division, and its subdivisions, were stipulated in such a way that they would allow standardization, and therefore a better organization for the construction of future itineraries.

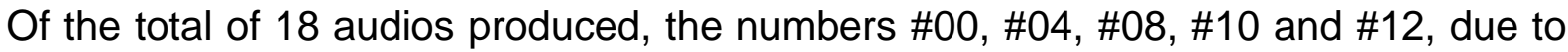
the nature of their proposals, did not comply with the above scheme. And, from the $\# 13$, because of the plurality among the suggestions of themes received, the narrative scheme underwent some changes in the section "Evolution". However, the essence of what was built in the scheme presented above, was preserved until the last subject posted

Table 2 shows the number of audios and topics addressed. 
Table 2 - Themes addressed to each audio.

\begin{tabular}{c|c}
\hline Número & Assunto \\
\hline$\# 00$ & O que é o EPTCast?"; \\
\hline$\# 01$ & Manual ou Intelectual? \\
\hline$\# 02$ & Onde estão as fontes? \\
\hline$\# 03$ & Natural ou Social? \\
\hline$\# 04$ & Não Confunda! 01 \\
\hline$\# 05$ & O que é... Ciência? \\
\hline$\# 06$ & A crise de 29 \\
\hline$\# 07$ & Globalização \\
\hline$\# 08$ & Matemática \\
\hline$\# 09$ & O que é Materialismo Histórico Dialético? \\
\hline$\# 10$ & Fala Docente! \\
\hline$\# 11$ & Percurso Histórico Estrutural da EP Brasileira \\
\hline$\# 12$ & Final de Temporada \\
\hline$\# 13$ & A Cientificidade da Música \\
\hline$\# 14$ & Educação Profissional e Propedêutica \\
\hline$\# 15$ & Redação \\
\hline$\# 16$ & Cursos Técnicos \\
\hline$\# 17$ & Novas Exigências e Velhas Transformações \\
\hline$\# 18$ & Formação de Professores para EPT \\
\hline
\end{tabular}

Until the audio \#16 Technical Courses, the time of each production was 15 minutes. From this, therefore, \#17 New Requirements and Old Transformations; and \#18 Teacher Training for PTSD, were produced and published with a total time of 12 minutes. This change was promoted on account of suggestions from the audience. 


\section{CAPTURE}

After the conclusion of the narrative scheme and the elaboration of the first script, the audio production began. To this end, the capture was performed through audacity software, version 2.3.1 (https://audacityteam.org) installed on a portable microcomputer model Lenovo IdeaPad 310 and with the aid of a generic condenser microphone, the BM-800 (Figure 2).

Figure 2 - Audio capture.

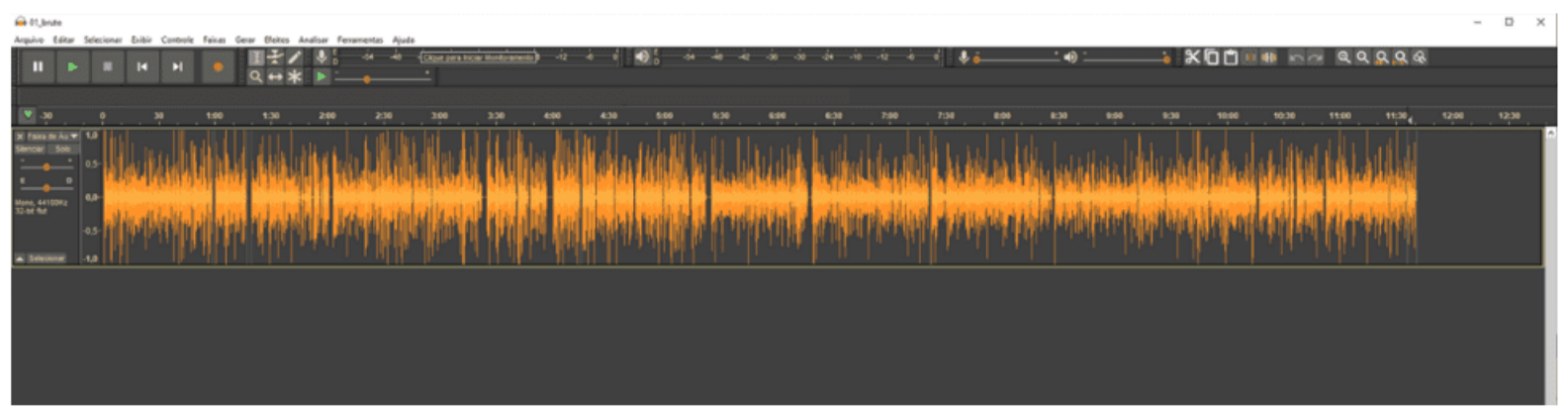

The audio capture represented the beginning of the process of materialization of the planned objective. Due to the lack of experience in what referred to the narration of written content for audio distribution, the recording size/volume was sometimes more than twice the time stipulated for each audio. The figure above shows the recorded content without the errors of the capture process.

\section{EDITION}

After capturing the audio and removing its surplus, the editing process was initiated. For this stage, the audio resources of the YouTube (https://youtube.com/audiolibrary) platforms were used for the insertion of music tracks, and Freesound.org (https://freesound.org) for the insertion of sound effects. Both platforms feature content without financial costs (Figure 3). 
Figure 3 - Audio editing.

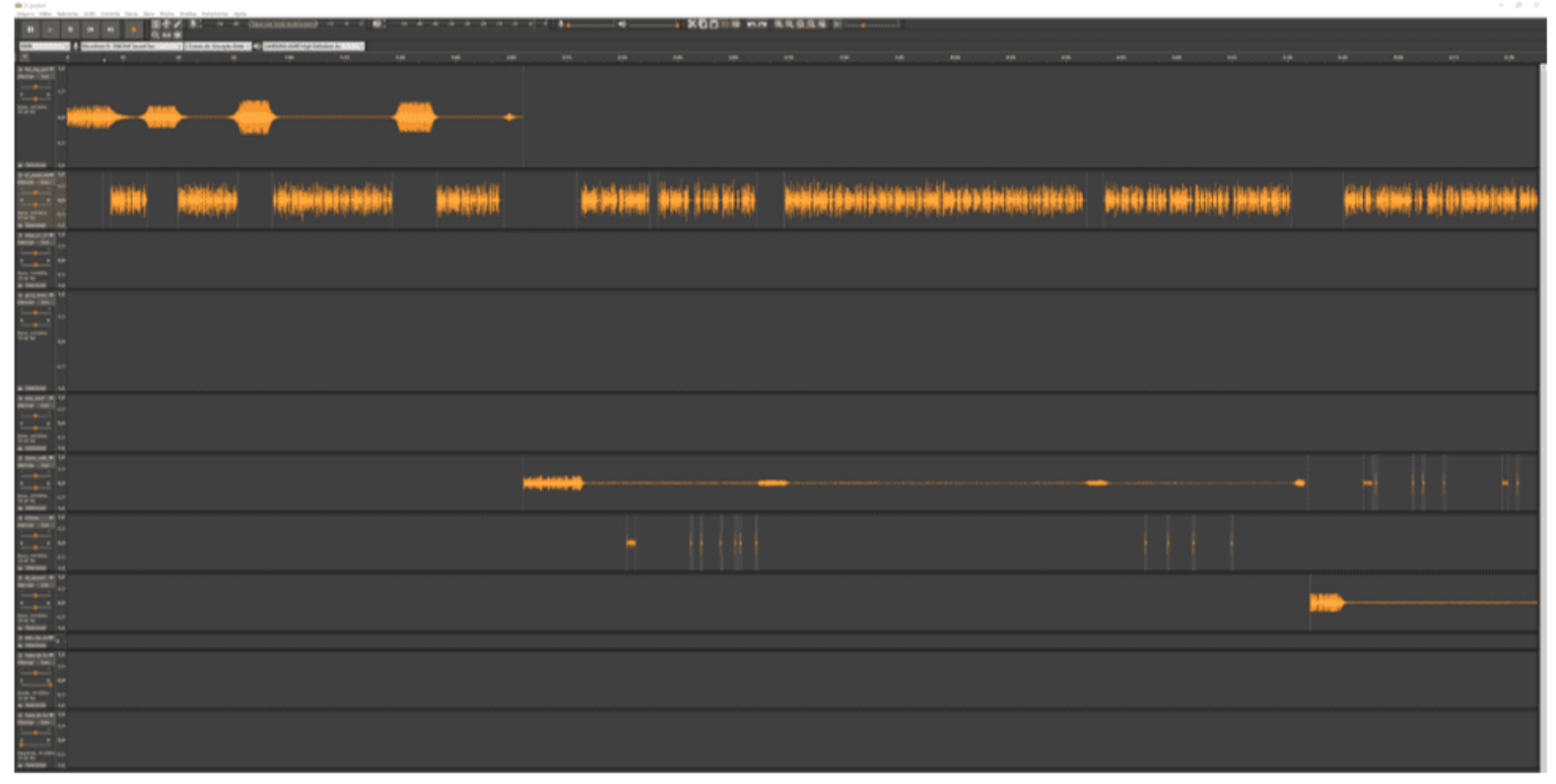

The option to insert music tracks and sound effects was the result of the experience of previous consumption of content distributed via podcast. Throughout the editing process, it was also perceived that this resource, at some level, presented itself as capable of softening the presence of certain unwanted insertions, coming from audio capture in the home environment.

In order to differentiate the narrator's speech with the original arguments of the research sources, the content had the rotating participation of 04 students of the Integrated High School of the Federal Institute of Education, being 02 of Amapá, Santana campus; and 02 of Rio Grande do Sul, Osório campus. In this sense, the invited students were responsible for narrating the direct citations inserted in the text of the script.

\section{DISTRIBUTION}

Among the large number of options for the distribution of EPTCast, we opted for the Anchor.fm - http://anchor.fm. This was a choice based on two fundamentals, namely: Total gratuity in its handling; and Automatic distribution of content posted on other platforms. 


\section{IDENTIFICATION OF THE MATERIAL}

By sending the content produced through the resource dedicated to this task (Click to upload or drag files here), theaudio was uploaded, thus allowing playback so that the quality of the content to be distributed could be checked (Figure 4).

Figure 4 - Insertion of the audio and the identification of the material.

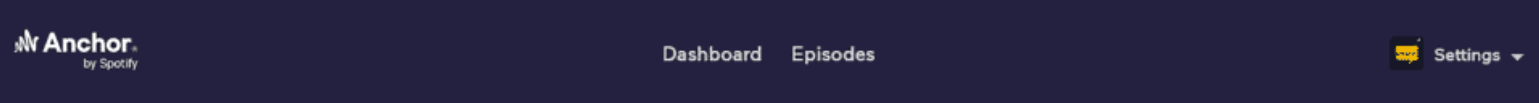

Create your episode

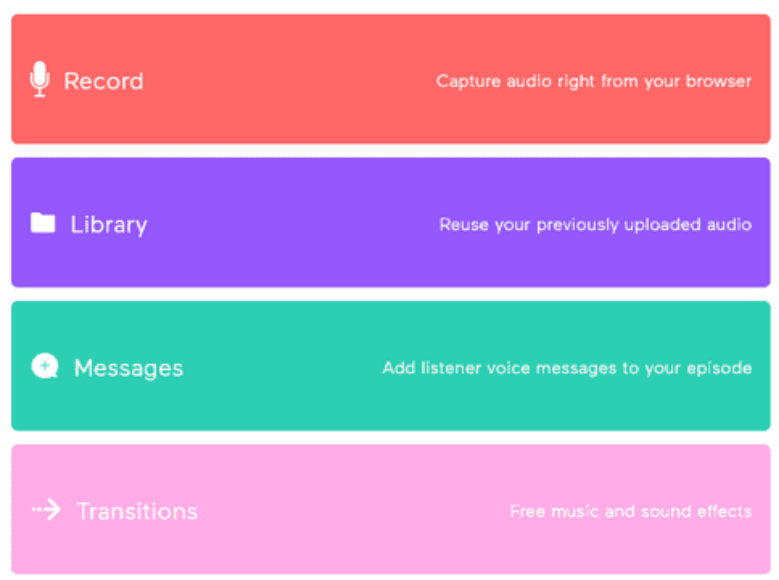

Save episode

(1) Click to upload or drag files here Audio and video uploads supported 0

$\# 00$ - O que éo

EPTCast un $14 \cdot 15: 00$

(5) Add a sponsored segment

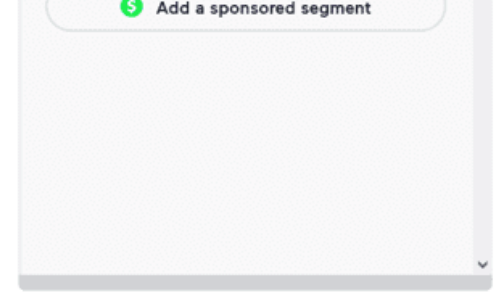

Preview Episode

After inserting the audio, the platform requested basic information to identify the content. These were: Title (Episode title), description (Episode description), season (Season number), content number (Episode number), content type between: complete, trailer or bonus (Full; Trailer; Bonus) and finally , whether this is user-friendly content or not (Clean; Explicit) (Figure 5). 
Figure 5 - Identification of the material.

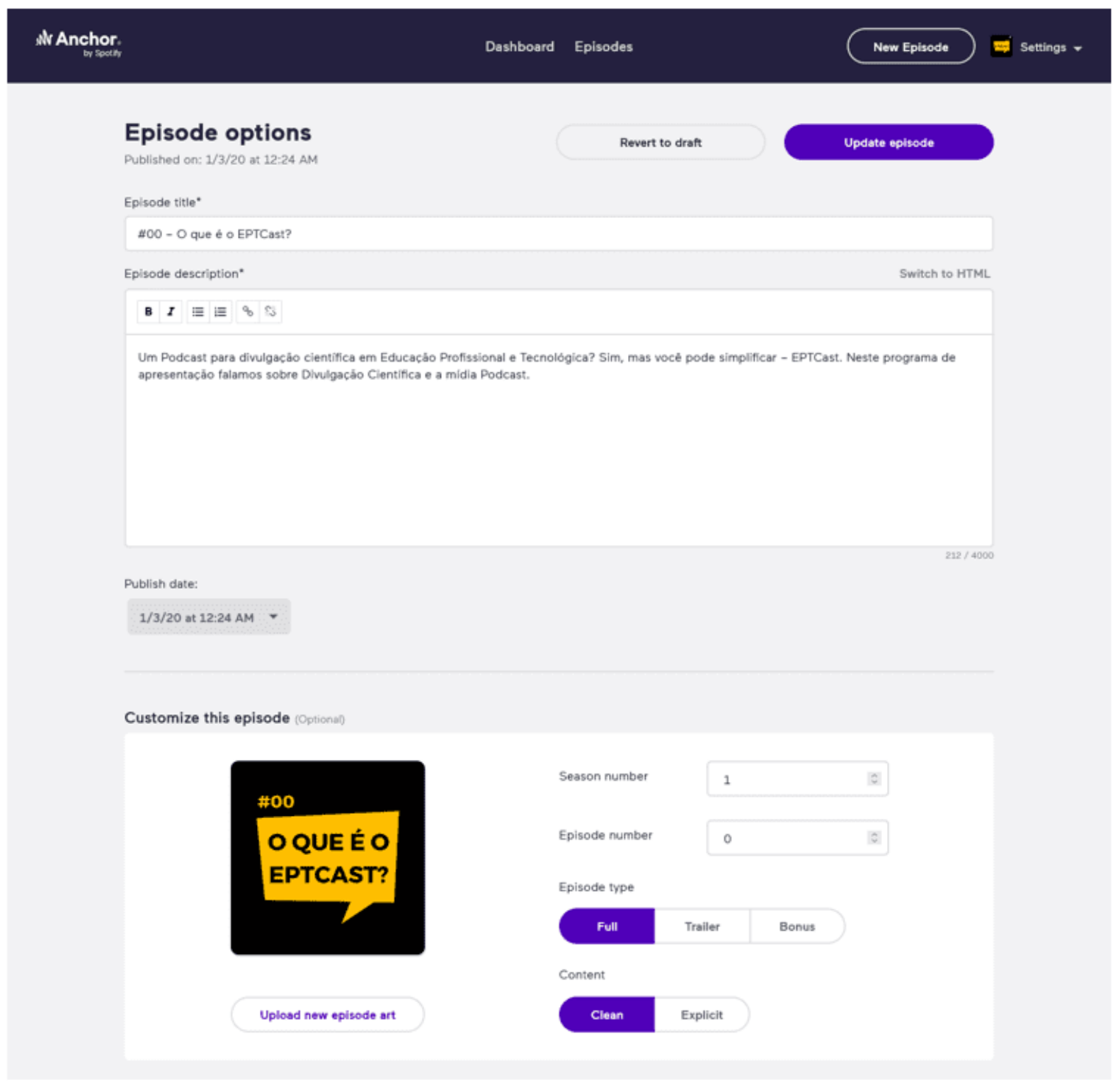

After the insertion of the information requested for the identification of the content, the audio was made available on this platform, and also in the music streaming services platform Spotify (https://spotify.com), thus allowing its consumption in the first moments. 


\section{DIGITAL AUDIO PLATFORMS}

Despite automation regarding the distribution process on other platforms, Anchor.fm did not perform this task at the same time on all platforms it is associated with. However, as sending audio increased EPTCast online content, it was noticed that access options were growing. In the posting of the \#07 Globalization, it was observed that the distribution reached its maximum number of platforms, 09 (Table 3 ).

Table 3 - Access platforms.

\begin{tabular}{c|c}
\hline NOME & ENDEREÇO (URL) \\
\hline Anchor & anchor.fm/eptcast \\
\hline Breaker & breaker.audio/eptcast \\
\hline Castbox & castbox.fm/channel/id2581365 \\
\hline Google Podcasts & google.com/podcasts?feed=aHROcHM6Ly9hbmNob3luZm0vc \\
\hline Apple Podcasts & podcasts.apple.com/us/podcast/eptcast/id1494934631 \\
\hline Overcast & overcast.fm/itunes1494934631/eptcast \\
\hline Pocket Casts & pca.st/8znyqbx5 \\
\hline RadioPublic & radiopublic.com/eptcast-WkaRNN \\
\hline Spotify & open.spotify.com/show/1hZ3KSkDDzOHuLmIPD6dh8 \\
\hline
\end{tabular}

The distribution through the selected platform presented itself as an experience of easy understanding and also of simple handling. The insertion in other digital platforms, free of charge, presented itself as an important differential since this activity proved to save time, a resource applied in the performance of other tasks of this Educational Product.

\section{FINAL CONSIDERATIONS}

Popularizing the scientificity of Brazilian Professional and Technological Education is what was intended through this work - which will not be the only one. Through what was exposed in the previous sections, therefore, it is intended to contribute to the popularization of a scientificity that is sometimes not yet understood as such. 
The social development of the popular working classes, through the development of a scientific culture, is our intention. In this sense, we make use of a decentralized media to popularize these issues that, despite being focused on the emancipation of those who need to, so far, are found and heard only within the reserved cycle.

From here, we find ourselves hopeful for greater and better initiatives aimed at popularizing these issues.

\section{REFERENCES}

MOIRAND, S. et ali. La vulgarisation scientifique au croisement de nouvelles sphères d'activité langagière. Bakhtiniana, Rev. Estud. Discurso, vol. 11 n. 2, p. 137-161, 2016.

DE-LARA-GONZÁLEZ, A.; DEL-CAMPO-CAÑIZARES, E. El podcast como medio de divulgación científica y su capacidad para conectar con la audiencia. Revista Mediterránea de Comunicación, vol. 09 n. 1 p. 347-359, 2018.

RIVERA SALAS, P.E.; MONTOYA MÁRQUEZ, O. R. Evaluación de los podcasts de noticias: un acercamiento a emisoras de la ciudad de puebla. Revista de Comunicación de la SEECI. n. 48, p. 109-123, 2019.

DANTAS-QUEIROZ, M. V.; WENTZEL, L. C. P.; QUEIROZ, L. L. Science communication podcasting in Brazil: the potential and challenges depicted by two podcasts. An. Acad. Bras. Cienc., v. 90, n. 2, p. 1891-1901, 2018.

MOURA, D. H. Ensino médio integrado: subsunção aos interesses do capital ou travessia para a formação humana integral? Educ. Pesqui., v. 39, n. 3, p. 705-720, 2013.

NDERITU PATRICK G. Bilingual naming of business premises, products and services in Murang'a county. Relatório de Projeto de Pesquisa (Mestre em Linguística) Universidade de Nairóbi, 2016. 
LIU, X. Application of the Internet Technology in the Visual Communication Design. In: Atiquzzaman M., Yen N., Xu Z. (eds) BDCPS 2019, AISC 1117, p. 1701-1706, 2020.

MILLER, D. W.; TOMAN, M. An analysis of rhetorical figures and other linguistic devices in corporation brand slogans. Journal of Marketing Communications, v. 22, n. 5, p. 474-493, 2014.

Submitted: June, 2021.

Approved: June, 2021. 